\title{
Mushroom as a Mechanism to Alleviate Poverty, Unemployment and Malnutrition
}

\author{
Mohammad Hassan Shakil ${ }^{1}$, Mashiyat Tasnia ${ }^{2}$, Ziaul Haque Munim³ ${ }^{3}$ Md. Humayun Kabir Mehedi ${ }^{4}$ \\ ${ }^{1}$ Graduate Studies Department, INCEIF-The Global University of Islamic Finance, Kuala Lumpur, Malaysia \\ ${ }^{2}$ Professional Studies Department, INCEIF-The Global University of Islamic Finance, Kuala Lumpur, Malaysia \\ ${ }^{3}$ Graduate Student, Research Institute of Supply Chain Management, Vienna University of Economics and Business, Vienna, Austria \\ ${ }^{4}$ Department of Business Studies, International Islamic University Chittagong, Bangladesh
}

\begin{abstract}
Mushroom is the most popular delicious, nutritious and medicinal vegetable in the world. Now it is considered as the most promising concept for crop diversification. It has been regarded as an effective means for poverty alleviation in less developed countries due to its potential for a quick, high return of profit on a small investment. Bangladesh is one of the most suitable countries in the world for Mushroom cultivation due to its favorable climate, cheap raw materials and labor cost and high market price. It is such an income generating concept that can alleviate poverty and eradicate malnutrition. It can also create employment opportunities for landless beggar, educated and uneducated youth, person with disabilities and adolescent men and women respectively. The primary objective of the study is to alleviate poverty, unemployment and malnutrition through cultivating and selling mushroom. The study is analytical and theoretical in nature and based on the secondary data. However, personal interview has been conducted to the mushroom farmers to depict the cost and profitability of Mushroom cultivation. The study finds that Mushroom cultivation can open a new opportunity for landless and unemployed people as it does not require any cultivable land and can be grown in a room by racking vertically. One can earn nearly TK $4-5$ thousands a month by investing only TK 10-15 thousands. So, it is possible to make a handsome profit by investing a small amount of capital and labor in Mushroom cultivation.
\end{abstract}

Keywords: Poverty Alleviation, Unemployment, Malnutrition, and Profitability

\section{INTRODUCTION}

Mushroom is the most popular delicious, nutritious and medicinal vegetable in the world. At present it is one of the most promising concepts for crop diversification in Bangladesh. The weather condition of Bangladesh is convenient for mushroom cultivation. On the other hand, it does not require any cultivable land and can be grown in room by racking vertically. As a result, its capital return as well as benefit per unit area is higher than any other vegetable in our country. It requires little capital, short time and trouble-free technique for cultivation. For that reason all types of people can participate in its cultivation. Hence, it can also generate huge employment opportunities for unemployed. The ingredients required for mushroom cultivation like sawdust, paddy straw, wheat straw, sugarcane baggage, waste paper, used cotton, dervishes etc are always available and cheap and no materials are not required to import from abroad for its cultivation. Moreover, no chemical components are necessary for its cultivation. It is an organic and Ecofriendly vegetable. Worn substrate of mushroom cultivation is one of the best sources of organic matter in the soil. Its cultivation may be "a lifeboat" for survival of the landless people who do not have any source other than their houses. Its cultivation can transfer as a cottage industry and create a huge prospect for export.

\section{Objectives}

The primary purpose of the study is to alleviate poverty, unemployment, and malnutrition through cultivating and selling mushroom. To support the key objective, some others take into consideration:

- to introduce high nutritious food for people suffering severe malnutrition;

- to improve the standard of life of unemployed and beggars;

- to generate income and food security of the people.

\section{MetHODOLOGY}

The present study is of analytical and theoretical in nature and based on secondary data. However, personal interview has been conducted from the mushroom farmers to depict the cost and profitability of Mushroom cultivation. Secondary information sources have been collected from various newspapers and magazines. Furthermore, different working papers, journals and articles have been studied to enrich the literature of the paper. An intensive desk research has been undertaken to collect published data. Microsoft office package have used for summarizing and illustrating the collected data systematically. 


\section{LITERATURE REVIEW}

Mushroom (Agaricus bisporus) production is a lucrative and profitable cottage industry for low income rural households (Lelley, 1988) and this industry is providing full and part time employment to rural and urban poor and marginal people in many developing countries (Ferchak and Croucher, 2001). Now mushroom is being cultivated in more than 100 countries of the world and the estimated total production is over 12 million tons (Suman and Sharma, 2007). Mushroom is considered as one of the important food items since ancient time and its consumption is being increased over the period for its significant role in human health, nutrition and diseases (Suzuki and Oshima, 1976; Uddin, et al., 2011). The edible mushrooms are also good source of protein, vitamins and minerals (Khan et al., 1981). Recently, unemployment is increasing rapidly both in developed and developing countries. In this situation, self-employment can be one important way to increase employment rate for small, marginal poor farm households for generating employment and earning extra money. They can easily cultivate mushroom in their home yard because it requires small piece of land where mushrooms can be grown. However, market linkage is the most appropriate in the context of the farmers' involvement and the market to supply goods to consumers (KIT et al., 2006; and Shepherd, 2007). Usually, marketing channel links the producers and consumers, and thereby supplying goods from producers to consumers. A large number of intermediaries are involved in the marketing channels and they earn their daily livelihoods. A few studies have been conducted which have focused on the production system of mushroom in Bangladesh (Kamal et al., 2009; Zamil and Cadilhon, 2009; Amin, 2002; Amin and Ruhul 2008; Sarker et al., 2007; and Uddin et al., 2011). In addition, a large number of researchers have been conducting research on mushroom related production system and management (Bano et al., 1979; Block et al., 1958; Han et al., 1977; Jong and Peng, 1975; Khan et al., 1981) in India, Nepal, China, Philippines, Thailand, Taiwan, Hong Kong and Pakistan. Work is also being done on human health, nutrition and diseases in other countries in the world (Agrahar-Murugkar and Subbulakshmi, 2005; Cheung and Cheung, 2005; GundeCimerman, 1999; Hawksworth, 2001).

\section{Edible Mushroom Varieties IN Bangladesh}

The Chinese have cultivated the mushroom for centuries. A total of 300 edible mushroom species, about 30 have been cultivated. Only about 14 species can be commercially grown because of the difficulties in artificial growing. These 14 species are: Bottom mushroom, Shiitake, Common oyster mushrooms, Phoenix tail mushroom, Golden Top oyster mushrooms, Enoki, Straw mushroom, Oyster mushroom, Money head mushroom, Wood ear, Hair wood ear, Silver ear and Ling zhi.

\section{Nutrition Value of Mushroom}

Mushrooms are a great source of B vitamins, including riboflavin, niacin, and pantothenic acid, which help to provide energy by breaking down proteins, fats, and carbohydrates. B vitamins also play a significant role in the nervous system.

\begin{tabular}{|c|c|}
\hline Elements & Nutrition Value \\
\hline $\begin{array}{l}\text { Pantothenic } \\
\text { Acid }\end{array}$ & $\begin{array}{l}\text { Helps with the production of hormones and also } \\
\text { plays a vital function in the nervous system. }\end{array}$ \\
\hline Riboflavin & Helps to maintain healthy red blood cells. \\
\hline Niacin & $\begin{array}{l}\text { Promotes healthy skin and makes sure the } \\
\text { digestive and nervous systems function properly. }\end{array}$ \\
\hline Minerals & Mushrooms are also a source of important. \\
\hline Selenium & $\begin{array}{l}\text { A mineral that works as an antioxidant to protect } \\
\text { body cells from damage that might lead to heart } \\
\text { disease, some cancers and other diseases of aging. It } \\
\text { also has been found to be beneficial for the immune } \\
\text { system and fertility in men. Many foods of animal } \\
\text { origin and grains are good sources of selenium, but } \\
\text { mushrooms are among the richest sources of } \\
\text { selenium in the produce aisle and provide } 8-22 \text { mcg } \\
\text { per serving. This is good news for vegetarians, whose } \\
\text { sources of selenium are limited. }\end{array}$ \\
\hline Ergothioneine & $\begin{array}{l}\text { A naturally occurring antioxidant that also may } \\
\text { help to protect the body's cells. Mushrooms } \\
\text { provide } 2.8-4.9 \mathrm{mg} \text { of ergothioneine per serving of } \\
\text { white, portabella or crimini mushrooms. }\end{array}$ \\
\hline Copper & $\begin{array}{c}\text { Helps to make red blood cells, which carry oxygen } \\
\text { throughout the body. Copper also helps to keep } \\
\text { bones and nerves healthy. }\end{array}$ \\
\hline Potassium & $\begin{array}{l}\text { An important mineral. It aids in the maintenance } \\
\text { of normal fluid and mineral balance, which helps } \\
\text { to control blood pressure. It also plays a role in } \\
\text { making nerves and muscles, including the heart } \\
\text { function properly. Mushrooms have } 98-376 \text { mg of } \\
\text { potassium per } 84 \text { gram serving, which is } 3-11 \\
\text { percent of the Daily Value. }\end{array}$ \\
\hline Beta-glucans & $\begin{array}{l}\text { Found in numerous mushroom species, have } \\
\text { shown marked immunity-stimulating effects, } \\
\text { contribute to resistance against allergies and may } \\
\text { also participate in physiological processes related } \\
\text { to the metabolism of fats and sugars in the human } \\
\text { body. The beta-glucans contained in oyster; } \\
\text { shiitake and split gill mushrooms are considered to } \\
\text { be the most effective. }\end{array}$ \\
\hline
\end{tabular}

\section{Medicinal Uses of Mushroom}

There are various chemical compounds found in mushrooms that reportedly have medicinal uses and benefits (Table 1). About 651 species representing 185 genera of mushrooms are reported to contain anti-tumour or immuno-stimulating polysaccarides that inhibit tumorigenesis. There is evidence that the $\beta$-D-glycans induce a biological response by binding to membrane complement receptor on immune effector cells. The lipid component of Agaricus was found to contain a compound with anti-tumour activity which was later identified as ergosterol (Takaku et al., 2001). Similarly the lipid fraction of Grifola exhibits antioxidant activity and inhibits enzymes that cause many chronic diseases including cancer (Inoue et al., 2002). The mushroom constituents not only inhibit progression 
of the disease by exerting direct cytotoxicity against tumour cells (Chang, 1996) but also up regulate other nonimmune suppressing mechanisms. These constituents are beneficial even in some established tumours (Bender et al., 2003) and isolates from mushroom cells have cytostatic compounds that induce apoptosis in leukamia cells. The chemicals produced by species of Ganoderma have antibacterial properties (Smania et al., 1999) and have been shown to inhibit the growth of bacteria such as Staphylococcus (Mothana et al., 2000). Steroids isolated from them are active against numerous gram negative and gram positive microorganisms (Kuznetsov et al.,2005). The mycelial extracts from Lentinula produce antiprotozoal activities against Paramecium (Badalyan, 2004). Mushrooms also have antiviral properties and several compounds isolated from Ganoderma are active against H1V-1 (El-Mekkawy et al., 1998; Ichimura et al., 1998) and are also known to possess antiviral activity against influenza virus type 1 . Although mushroom has numerous medicinal uses, some of the attributes of them are listed here:

Table 1: Chemical compounds and attributes of Mushroom

\begin{tabular}{|l|c|}
\hline Chemical Compounds & Attributes \\
\hline Peptido glycans & Anti-tumour \\
\hline Ergosterol & Anti-tumour \\
\hline Lipid fraction & Anti-oxidant \\
\hline Steroids, hydroquinones & Anti-bacterial \\
\hline Oxalic acid & Anti-protozoal \\
\hline Schizophyllan & Anti-tumour \\
\hline Epicorazin & Anti-microbial \\
\hline Ganoderic acid & Anti-viral (HIV) \\
\hline Ganodric acid, lucidadiol & Anti-viral (influenza) \\
\hline Lignins & Anti-viral (HIV) \\
\hline Polysaccarides & Anti-viral (HIV) \\
\hline Velutin & Anti-viral (HIV) \\
\hline Illudins & Cytotoxic \\
\hline Triterpenes & Apoptosis \\
\hline Polysaccarides & Antiangiogenic \\
\hline Hispolon, hispidin & Anti-allergic \\
\hline Ergosterol peroxide & Anti-allergic \\
\hline
\end{tabular}

Why Mushroom should cultivate

- Mushrooms can be grown on small, medium and large scale to accomplish personal consumption or to start commercially.

- It can be produced and sold within 2 to 4 months. It can be sold freshly direct from the Farm or in the local market.

- Physically disabled people are fully capable of accomplishing all necessary tasks in mushroom cultivation, although some modifications in constructions and equipment may need. Specific tasks may require because of certain disabilities.

- Persistently ill or weak people can work in a cooler environment as mushrooms grow underneath the shade. It reduces physical exertion associated with open cultivation similar to rice and small fruit.

\section{Anticipated Cost and Profitability of MuShroOM CULTIVATION}

Among several income generating activities like dairy and poultry industries, Mushroom cultivation also has a new opportunity of earning and has become most popular income generating activity among a good number of landless farmers and unemployed people. But the farmers are facing many problems such as unavailability of spawns or seeds, inadequate loans, lack of promotion and so on. It can be grown in the small space of a farmer's own house for small scale of production and whereby they can afford to invest in a small scale capital which generates income that aids in the family support. Basically Mushroom production is labor and management intensive and it takes only a considerable amount of knowledge and capital investment to set up a production system. The farmer sells fresh Mushrooms to the Mushroom center or merchants only at Tk. 110-130 per kg. But if they can sell it in Dhaka, the price would be at least Tk.200.

Table 2 depicts how a farmer can produce mushroom with the support of a small space, capital, and labor. From the table below, we can clearly see that by investing an average amount of Taka 10000-15000 an investor can produce approximately $60-90 \mathrm{~kg}$ Mushroom per month. The most convenient thing in the cultivation process is that it needed a small space to cultivate the mushroom, and the labor cost is relatively cheaper than any other cultivable crops.

Table-02: Estimated Cost and Production of Mushroom Firm

\begin{tabular}{|l|c|c|c|c|}
\hline Area/Size & $\begin{array}{l}\text { Capital } \\
\text { Needed }\end{array}$ & $\begin{array}{l}\text { Man Power } \\
\text { Needed } \\
\text { (Per month) }\end{array}$ & $\begin{array}{l}\text { Total Cost } \\
\text { (Per Month } \\
\text { In BDT) }\end{array}$ & $\begin{array}{l}\text { Approximate } \\
\text { Production } \\
\text { (Per month) }\end{array}$ \\
\hline (05feet/05feet) & 12,000 & 02 & 1500 & $60 \mathrm{~kg}$ \\
\hline (06feet/03feet) & 13000 & 02 & 900 & $60 \mathrm{~kg}$ \\
\hline (09feet/05feet) & 14,000 & 02 & 1300 & $80 \mathrm{~kg}$ \\
\hline (10feet/03feet) & 11000 & 02 & 1400 & $69 \mathrm{~kg}$ \\
\hline (10feet/05feet) & 18000 & 02 & 1200 & $100 \mathrm{~kg}$ \\
\hline
\end{tabular}

Source: Personal Interview

Table-03: Net Profit through Mushroom Cultivation

\begin{tabular}{|l|c|c|c|c|c|}
\hline $\begin{array}{l}\text { Total } \\
\text { Production } \\
\text { (Per } \\
\text { month) }\end{array}$ & $\begin{array}{c}\text { *Total } \\
\text { Revenue } \\
\text { (Per } \\
\text { month) } \\
\text { (BDT) }\end{array}$ & $\begin{array}{c}\text { Total } \\
\text { Cost } \\
\text { (Per } \\
\text { month) } \\
\text { (BDT) }\end{array}$ & $\begin{array}{c}\text { Labor } \\
\text { Cost } \\
\text { (Per } \\
\text { month) } \\
\text { (BDT) }\end{array}$ & $\begin{array}{c}\text { Materials } \\
\text { Cost (Per } \\
\text { month) } \\
\text { (BDT) }\end{array}$ & $\begin{array}{c}\text { Net Profit } \\
\text { (Per } \\
\text { month) } \\
\text { (BDT }\end{array}$ \\
\hline $\mathbf{6 0} \mathbf{k g}$ & 7,200 & 1,500 & 1200 & 300 & 5,700 \\
\hline $\mathbf{6 0} \mathbf{~ k g}$ & 7,200 & 900 & 750 & 150 & 6,300 \\
\hline $\mathbf{8 0} \mathbf{~ k g}$ & 9,600 & 1,300 & 1100 & 200 & 8,300 \\
\hline $\mathbf{6 9} \mathbf{k g}$ & 8,280 & 1,400 & 1200 & 200 & 6,880 \\
\hline $\mathbf{1 0 0 k g}$ & 12,000 & 1,200 & 1000 & 200 & 10,200 \\
\hline \multicolumn{5}{|c}{ * Average Price- 120 Taka per kg } \\
\hline
\end{tabular}

Table 3 depicts that the total revenue is much higher than the total cost of mushroom cultivation and the labor, and the material cost is relatively cheaper. The average net profit in mushroom cultivation ranges from Taka 500010000. So, it is clear that the profitability is higher in mushroom cultivation. 


\section{RECOMMENDATIONS}

Mushroom has already been a significant crop in developed countries. Due to its low production cost and higher market price it has been found more profitable in comparison with other agro-economic crops. The study depicts that having a poor academic background and only with a little knowledge, investors made a handsome profit with their little investment. Moreover, it can be stipulated that if the educated people involved in mushroom cultivation, they can earn a considerable income from this sector. However, landless beggars can also cultivate Mushroom by taking financial help from social enterprise or NGOs like Grameen Bank, BRAC and so on. The profit margin of little capital indicates that Mushroom cultivation can be the key source of income if it can nurture professionally.

\section{Concluding Remarks}

As the soil and climatologically situation of this region are very suitable for mushroom cultivation, Bangladesh has a vast prospect of mushroom cultivation. It is possible to create employment opportunities for landless beggar, educated and uneducated youth, person with disabilities and adolescent men and women respectively. Moreover, there is a huge prospect to earn a huge amount of foreign currency by exporting Mushroom after meeting the internal demand. Therefore, government and private initiative is required to encourage people in Mushroom farming. By providing training to the unemployed people, supply of Mushroom spawns, providing flexible loan facilities, ensuring suitable price, reducing the effects of middleman and creating better opportunity for mushroom marketing will undoubtedly bring this sector to a boom and will eventually contribute significantly to the economy of the country.

\section{REFERENCES}

Agrahar-Murugkar, D. and Subbulakshmi, G. 2005. Nutritional Value of Edible Wild Mushrooms collected from the Khasi Hills of Meghalaya. Food Chemistry, 89: 599-603.

Amin, S. R. 2002. Performance of Different Oyster Mushroom (Pleurotus spp.) Varieties. M.S. Thesis, Bangabandhu Sheikh Mujibur Rahman Agricultural University, Gazipur, 1-50 pp.

Amin, S., and Ruhul, M. 2008. Mushroom in Bangladesh: Past, Present, and Future. Abstract of the Annual Botanical Conference 2007, March 7-9, Abstract no - 122, JU, Savar, Dhaka, 61p.

Badalyan SM (2004) Antiprotozoal activity and mitogenic effect of mycelium of culinary, medicinal shiitake mushroom Lentinus edodes (Berk.) Singer (Agaricomycetidae). Int J Med Mushrooms 6: 131-138.

Bano, L. Rajarathnam, S., and Nagraja. N. 1979, Some Aspects on the Cultivation of Pleurotus flagellates in India, Mushroom Science, 10(2): 597-608.

Bender S, Dumitrache CN, Backhuas J, Christie G, Cross RF, Lonergan GT (2003) A case for caution in assessing the antibiotic activity of extracts of culinary medicinal Shiitake mushroom [Lentnus edodes (Berk.) Singer] (Agaricomycetidae). Int J Med Mushrooms 5: 31-35.
Block, S. Tsao, S. and Han, I. 1958. Production of Mushroom from Sawdust. Journal of Food Chemistry, 6: 923-927.

Chang ST (1996) Mushroom research and development -equality and mutual benefit. Proceedings of the 2nd International Conference on Mushroom Biology and Mushroom Products. Pennsylvania State University, Pennsylvania, USA pp.1-10.

El-Mekkawy S, Meselhy MR, Nakamura N, Tezuka Y, Hattori M, Kakiuchi N (1998) Anti-HIV 1 and anti-HIV-1 protease substances from Ganoderma lucidum. Phytochem 49: 1651-1657.

Farooqi I(1998). Ahadith Mein Mazkoor Nabatat, Adwiya Aur Ghiza in. Ilm-o-Irfan

Gunde-Cimerman, N. 1999. Medicinal Value of the Genus Pleurotus (Fr.) P. Karst (Agaricles S. R., Basidiomycetes), International Journal of Medicinal Mushrooms, 1:69-70.

Han, Y. H. Chen., K. M. and Cheng, S. 1977. Characteristics and Cultivation of New Pleurotus In Taiwan. Mushroom Science, 9(2):167-173.

Hawksworth, D. L. 2001. Mushrooms: The Extent of the Unexplored Potential, International Journal of Medicinal Mushrooms, 3:333340.

Inoue A, Kodama N, Nanba H (2002) Effect of maitake (Grifola frondosa) D-fraction on the control of the $\mathrm{T}$ lymph node Th1/Th-2 proportion. Biol Pharm Bull 25: 536-540.

Kamal, A. S. Begum, F. and Khair, S. 2009. Mushroom Production in Bangladesh: Scenario and Potentialities. SAARC Journal of Agriculture, 7(2):91-105.

Khan, S. M. Kausar, A. G. and Ali, M. A. 1981. Yield Performance of Paddy Straw in Pakistan. Mushroom Science, 2(1):675- 687.

KIT, Mali, F. IIRR, 2006. Chain Empowerment: Supporting African Farmers to Develop Markets, Amsterdam: Royal Tropical Institute.

Kuznetsov OI, Milkova EV, Sosnia AE, Sotnikova NI (2005) Antimicrobial action of Lentinus edodes juice on human microflora. Mikrobiol Epidem Immunobiol 1: 80-82.

Lelley, J. 1988, Growing Edible Mushrooms-Still a Generally Neglected Opportunity, Gate 4, 30-34 pp.

Mothana RAA, Jansen R, Julich WD, Lindequist U (2000) Ganomycin $\mathrm{A}$ and $\mathrm{B}$, new antimicrobial farnesyl hydroquinones from the basidiomycete Ganoderma pfiefferi. J Nat Prod 63: 416-418.

Pulishers, 9-lower Mall, Aqab Mian Market, Urdu Bazar Lahore. Pp. $151-152,168$

R. 2007, Effect of Frequency of Watering on the Growth and Yield of Oyster Mushroom (Pleurotus ostreatus (Jacquin ex Fr.) Kummer), Bangladesh Journal of Mushroom, 1(1): 29-37.

Sarker, N. C. Hossain, M. M. Sultana, N. Mian, I. H. Karim, A. J. M. S. and Amin, S. M.

Smania JA, Monache DF, Smania EFA, Cuneo RS (1999) Antibacterial activity of steroidal compounds isolated from Ganoderma applanatum (Pers.) Pat. (Aphyllophoromycetidae) Fruit body. Int J Med Mushrooms 1: 325-330.

Suman, B.C. and Sharma, V.P. 2007. Mushrooms Cultivation in India, Daya Publishing House, Delhi.-110035, 18-22 pp.

Suzuki, S. and Oshima, S. 1976. Influence of Shii-te-ke (Lentina edodes) on Human Serum Cholesterol. Mushroom Science, 1:463-T.

Takaku T, Kimura Y, Okuda H (2001) Isolation of an antitumor compound from Agaricus blazei Murill and its mechanism of action. J Nutr 131: 1409-1413.

Zamil, M. F. and Cadilhon, J. J. 2009. Developing Small Production and Marketing Enterprise: Mushroom Contract Farming in Bangladesh. Development in Practice, 19(7): 923-932.

\section{How to Cite}

Shakil MH, Tasnia M, Munim ZH and Mehedi MH. 2014. Mushroom as a Mechanism to Alleviate Poverty, Unemployment and Malnutrition Asian Business Review, 4, 109-112. 